\title{
Influence of the Ignition Mixture Particle Size on Rocket Motor Igniter Pressure Gradient
}

\author{
Nikola Gligorijevic ${ }^{1)}$ \\ Jovica Nešicí ${ }^{1)}$ \\ Jovica Bogdanov ${ }^{2)}$ \\ Bojan Pavković ${ }^{1)}$ \\ Saša Živković ${ }^{1)}$ \\ Bojan Tanaskovski ${ }^{1)}$
}

\begin{abstract}
The paper discusses the influence of ignition mixture granulation onto the regime of rocket motor ignition. Igniter tests were performed in manometric bomb and pressure distribution was measured. In each test different granulations of the same mixture in powder form were tested. After that, two different ignition mixture compositions in the form of pressed tablets were tested. Total masses of ignition mixtures were equal in all the tests.

In the first series of the igniter tests, very carefully chosen different granulation of the powder was used in each test, with the particles in a narrow range. From one to another test, only the granulation of the mixture was changed. The purpose was to determine if there exists an influence of the mixture granulation onto the pressure gradient and thus also onto the regime of the rocket motor ignition. It turned out, surprisingly, that there were no visible differences in the regimes of pressure increase due to the different granulation of the ignition mixtures.

In another series of tests the mixture was prepared in the form of pressed tablets, with various sizes from test to test. Two different mixtures were tested, and the mass of each single charge of the igniter was the same as in the first series of tests. It is shown that the form of the pressed tablets, as well as their composition, may considerably affect the mode of rocket motor ignition
\end{abstract}

Key words: rocket motor, ignition, igniter, pressure, pressure gradient, ignition mixture, granulation, tablets.

\section{Introduction}

GNITABILITY of a solid propellant rocket motor is Iaffected by different factors [1] including propellant properties, grain configuration, its surface shape and roughness, igniter box position in the motor combustion chamber, ignition propellant mixture mass and composition, the content of solid particles in combustion products of the igniter, velocity of the igniter hot gases relative to the burning surface of the propellant grain, cavity volume, design of nozzles and parameters of the nozzle opening, etc [2].

It is customary for total mass and formulation of the igniter charge to be declared as the most important parameters of the rocket motor igniter. In most cases, the ability of an igniter for successful ignition of the propellant grain is directly proportional to the weight of the ignition mixture.

From our previous experience, during development of the guided missile "Grom" some occurrences of sustainer rocket motor extinction arose due to the depressurization caused by rapid opening of the nozzle [3].

This problem had been solved by reducing the weight of the ignition mixtures, thus achieving better control of the ignition process, so that the pressure gradient was reduced. Thus, it was possible for the igniter and propellant grain together to generate more heat in the chamber before opening the nozzle (Fig.1) [3].

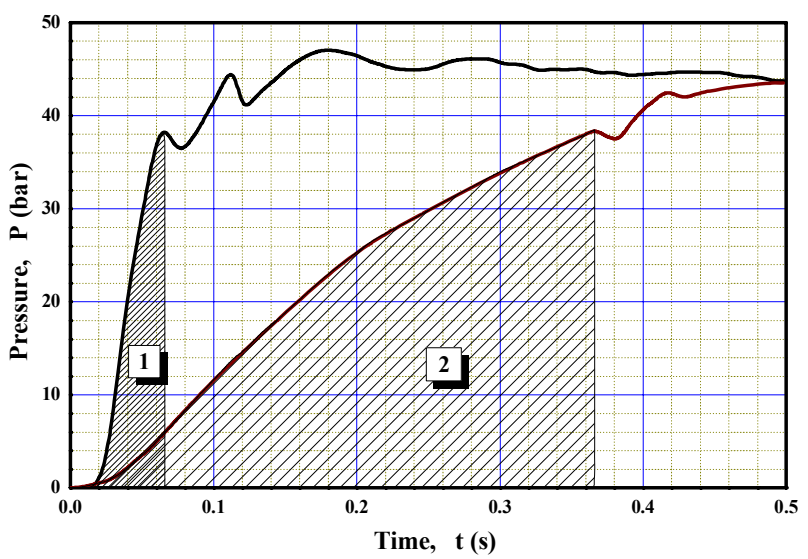

Figure 1. Different modes of pressurization in the ignition phase

This is only one of the cases from the practice, where the ignition speed was not decisive, and where the long duration of the ignition process was acceptable.

Unlike this case, during development of our sustainer rocket motor of the guided missile "Bumbar", it was explicitly asked from the designer to achieve quick and reproducible ignition. The technical requirement was the cause of providing a reliable and fast immersion of thrust vector control (TVC) executive elements (interceptors) into the

\footnotetext{
1) Military Technical Institute (VTI), Ratka Resanovića 1, 11132 Belgrade, SERBIA

2) University of Defence, Military Academy, Pavla Jurišića Šturma 33, 11000 Belgrade, SERBIA

Correspondence to: Nikola Gligorijević; e-mail: nikola.gligorijevic@gmail.com
} 
gaseous combustion products at the nozzle exit, immediately after the rocket leaves out the launcher tube.

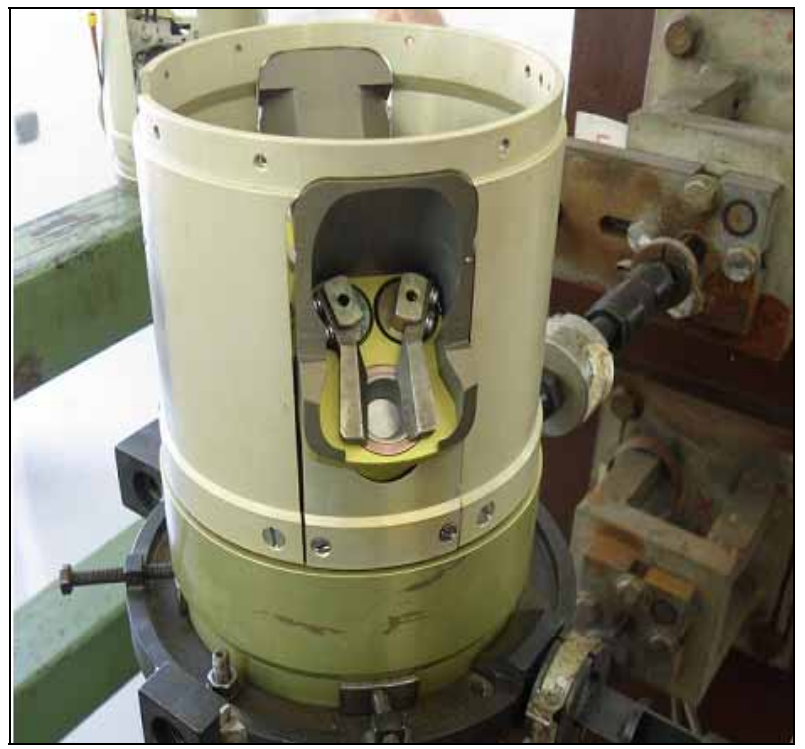

Figure 2. TVC executive elements (interceptors)

In this case, a sufficient mass of ignition mixture was required to ensure reliable and rapid ignition, but also to prevent the occurrence of motor extinguishing (Fig.3) [4].

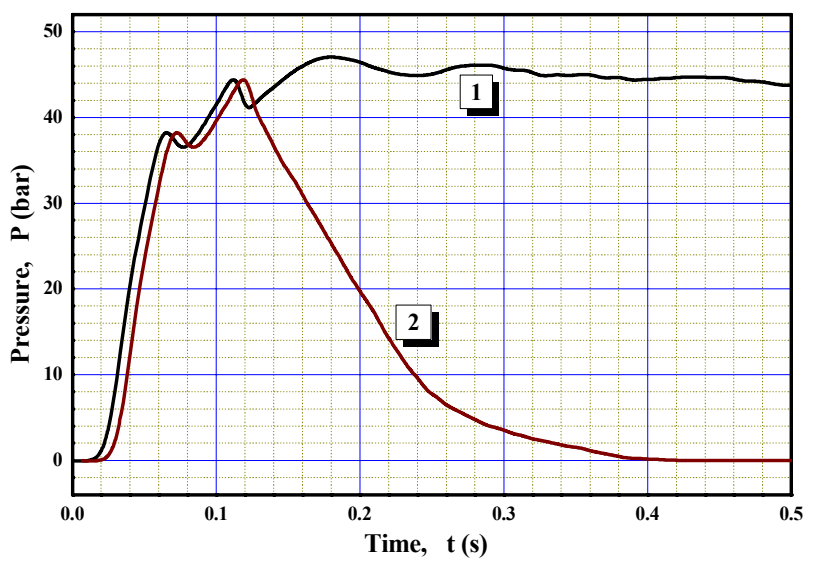

Figure 3. An example of pressure decrease (extinguishing)

These two examples show that a good ignition regime has to be achieved by a compromise between the lowest possible mass of the ignition mixture that will provide enough energy for ignition, but, on the other side, that will not cause too large pressure gradient. The fast pressure increase can lead to rapid decompression due to the nozzle opening, which could lead to the motor extinction.

According to Sutton [1], among the parameters that affect the process of ignition, there is no mentioning of the particle size of the ignition mixtures, or the mixture tablet size and shape.

It is said in NASA report [5] that appropriate charge formulations and pellet sizes should be established on the basis of experience, test results, and fundamental design information. A similar conclusion can be found in other literature in the field of solid propellant rocket motors [6, 7].

We can assume that these parameters may have an impact on the pressure gradient during ignition, although from the literature it is not known that the influence of the mixture granulation has been considered.

Our experience in the development stage confirms the strong influence of the ignition pellet's size [3].
It was also shown that there is a strong influence of the mixture quality, when it is purchased from different manufacturers $[8,9]$.

In this paper the results of ignition tests in the manometric bomb are shown and the effect of mixtures granulation on ignition process was analyzed. Then, the results of testing two different compositions in the form of pellets are also shown.

In the first step, simple measurements were made in order to determine in detail the properties of well known ignition mixture, which was adopted for the igniter charge of the rocket motor for the antitank missile. The purpose was to find a possibility of eventual improvements of the ignition regime. The final task was to try to define a method of ignition process control, by controlling the pressure gradient of the igniter itself.

The basis for comparison were the results of testing this mixture in the manometric bomb, that had been done a few years ago, in the final stage of development. (Figures 4 and 5).

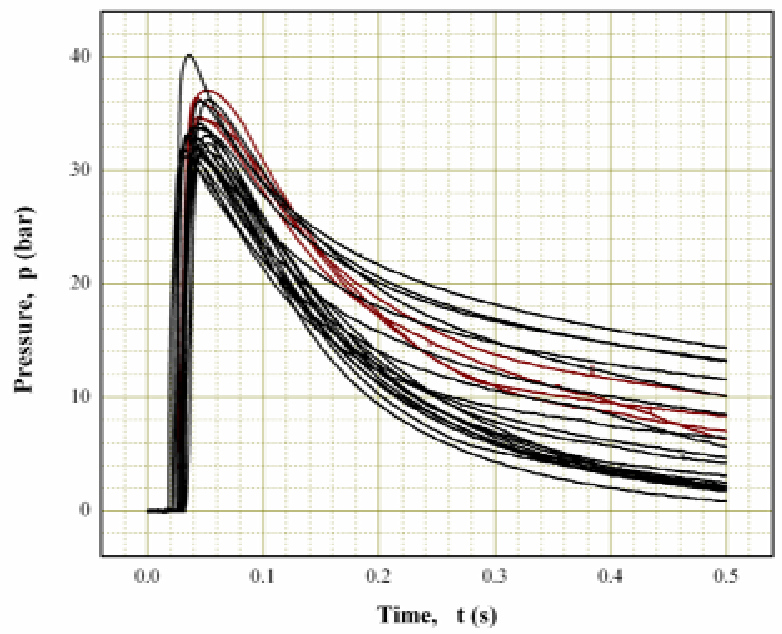

Figure 4. Pressure distribution in manometric bomb

The differences between the curves in Fig. 4 in the second stage are not authoritative for the analysis. After reaching the pressure maximum, the conditions of heat transfer through the walls of the manometric bomb chamber are different in each test.

On the pressure curves, only the periods before reaching the maximum are important. The visibility is better in Fig.5, where the curves are shown in a different time scale.

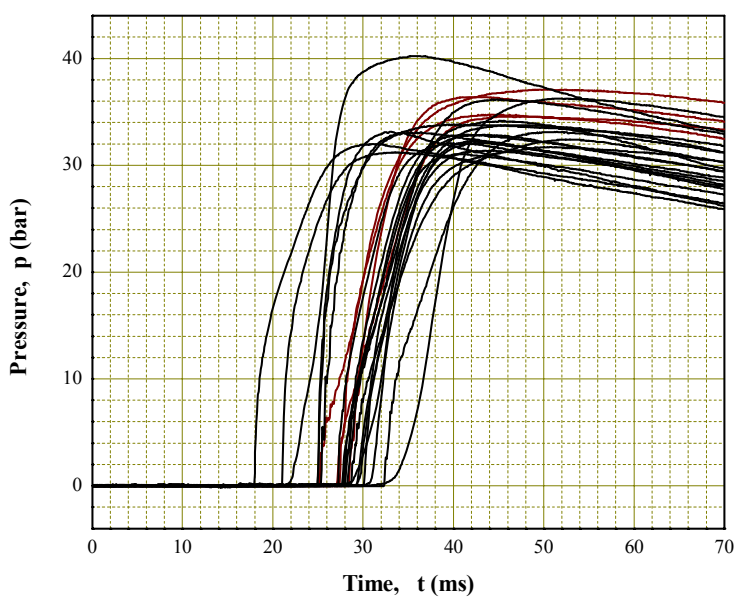

Figure 5. Pressure distribution

The basic idea was to check whether it is possible to change the pressure gradient of the igniter itself in a controlled manner, changing the medium particle size of the powder mixture. 


\section{Experiment}

Separation of different mixture granulations

It was determined that the diameters of the mixture particles were arranged in the range 50-1200 microns. Using the powder sieving device (Fig.6), nine groups of different particle sizes of the mixture were allocated.

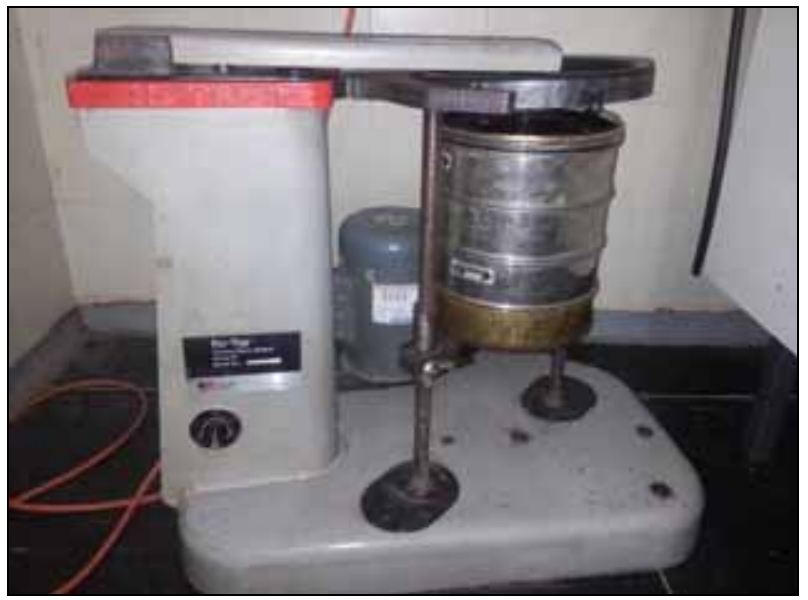

Figure 6. Apparatus for sieving the mixture

Particle sizes of the each allocated group varied in the narrow ranges between 100 and 150 microns (Fig.7).

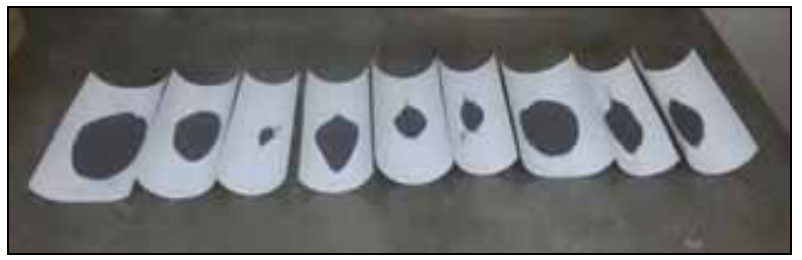

Figure 7. Different groups of sieved mixture

In order to make an overview of the powder arrangement in the mixture, the mass fractions of different particle sizes were determined. The diagram of various fractions distribution is shown in Fig. 8 . The mean particle size of about $300 \mu \mathrm{m}$ was determined, and it was also found that two main sizes dominate (75 and $700 \mu \mathrm{m}$ ). In general, the method of determining the mean particle size of the mixture is complex and not reliable, and it is actual wherever the problem of small particles is present $[10,11]$.

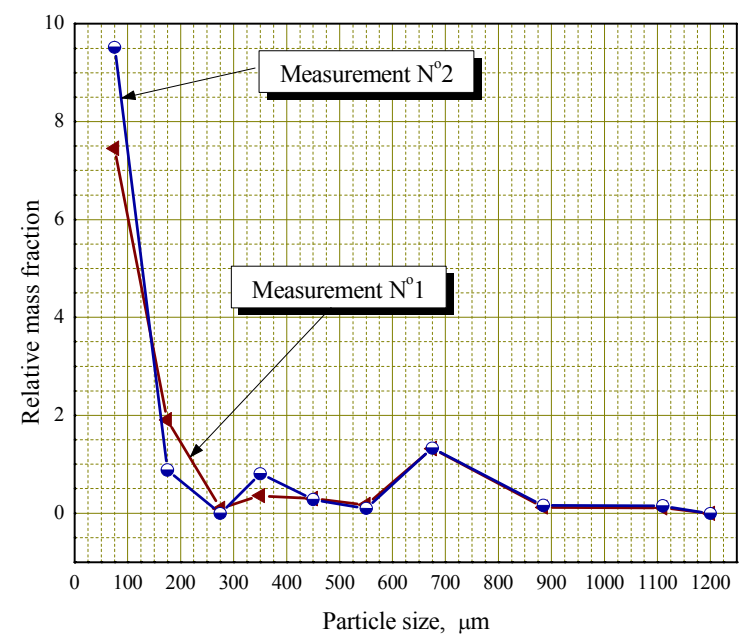

Figure 8. Relative mass fractions vs. particle size

\section{Testing with different granulations of ignition mixture}

The so-formed several groups of mixture powder particles were used to create igniters in the form of bags of the same weight with precisely defined particle sizes (Fig.9).

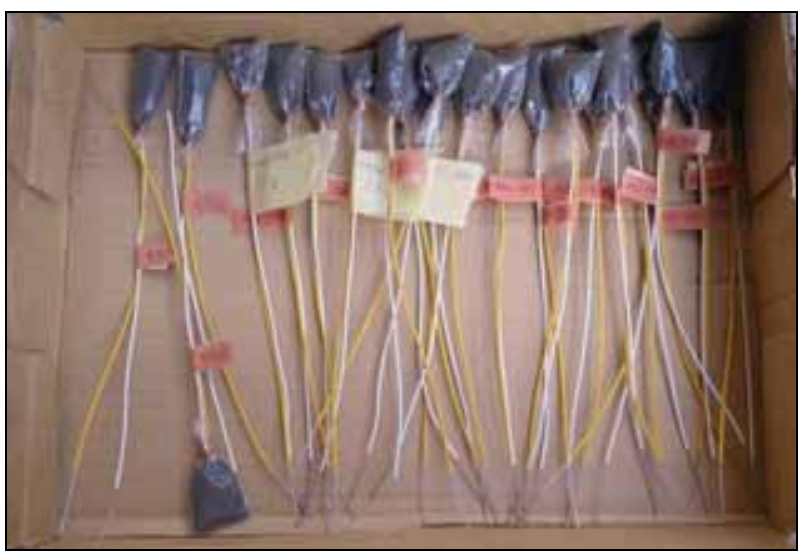

Figure 9. Ignition bags

The tests were performed in the manometric bomb (Fig.10).

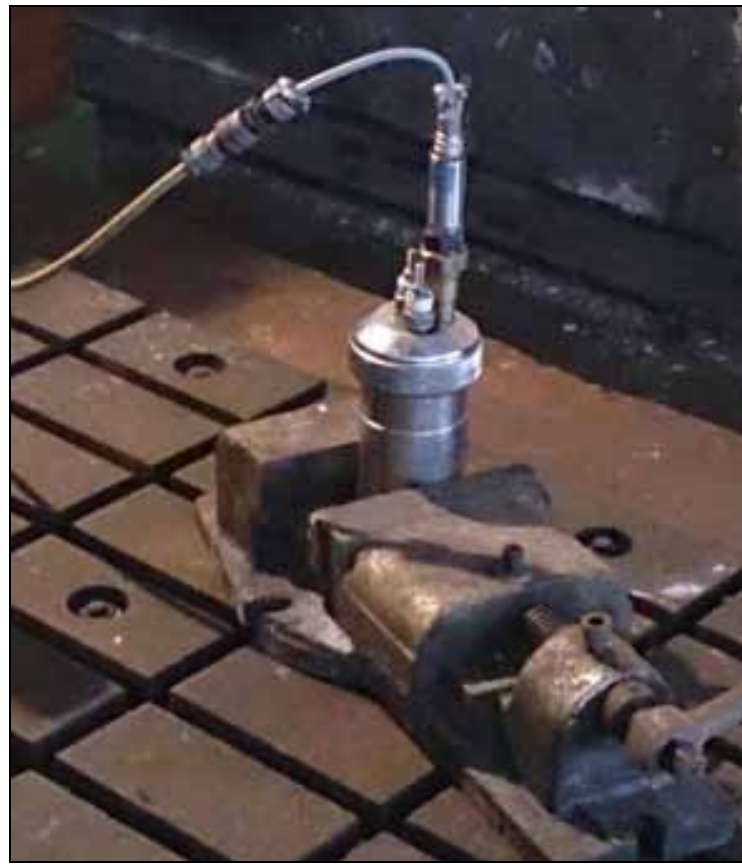

Figure 10. Manometric bomb

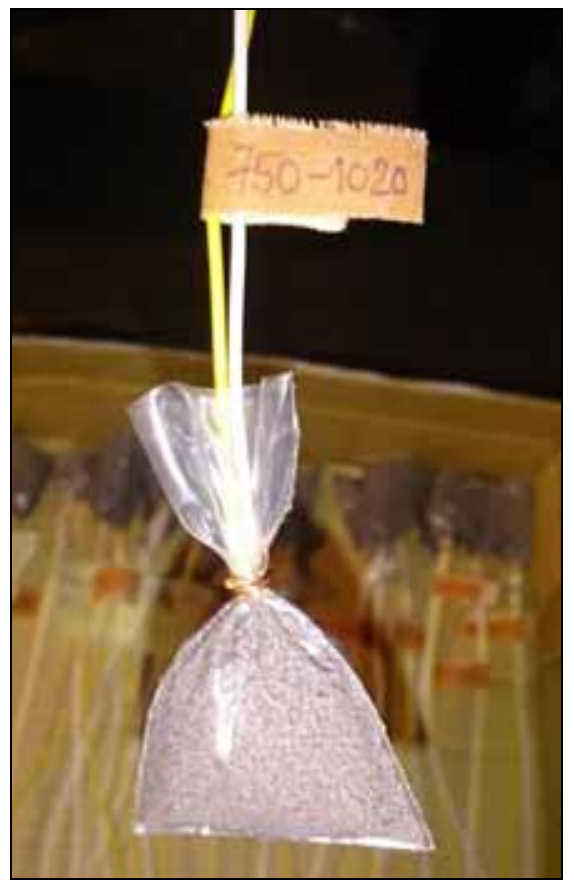

Figure 11. Ignition mixtures in the bag 


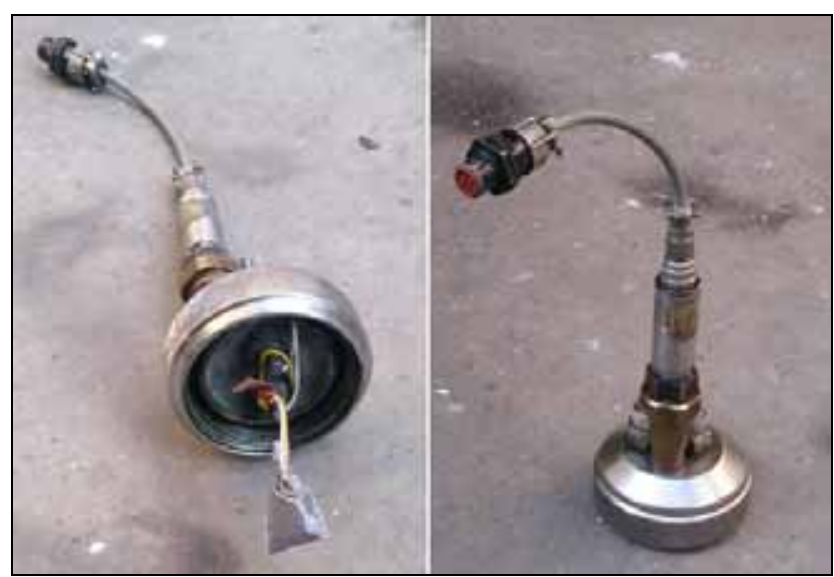

Figure 12. Manometer bomb cover with the igniter and the pressure transducer

The igniter (Fig.11) is mounted into the cover of manometric bomb (Fig.12) where the pressure transducer is connected.

In each test, regardless the different particle sizes of the mixture, the same amount of the mixture was used. Fig.13 shows only some of the pressure distributions measured in different tests.

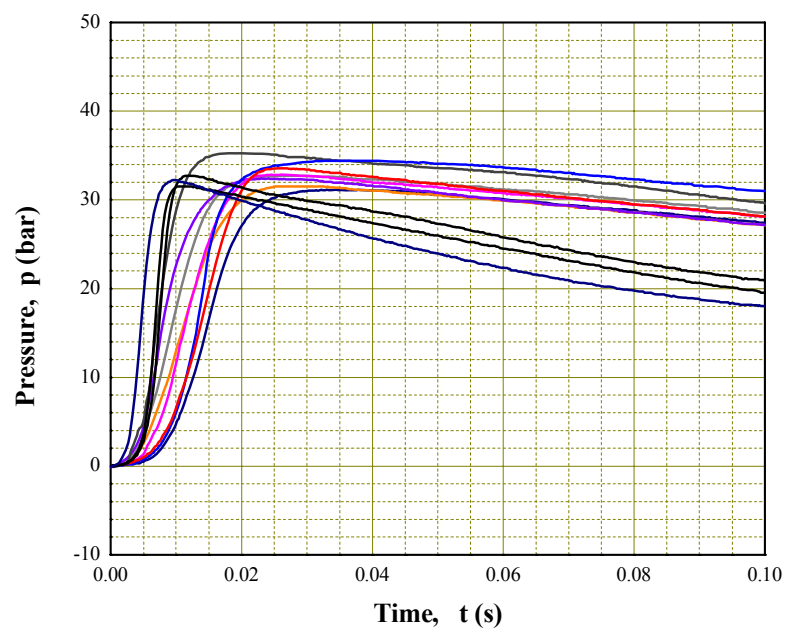

Figure 13. Pressure distributions in different tests

Pressure curves in Fig.13 are translated into the same start point for better comparisons.

Another set of measurements, in which the pressure curves are not translated into the zero point is shown in Fig. 14. Similar diagrams have been measured in all other tests.

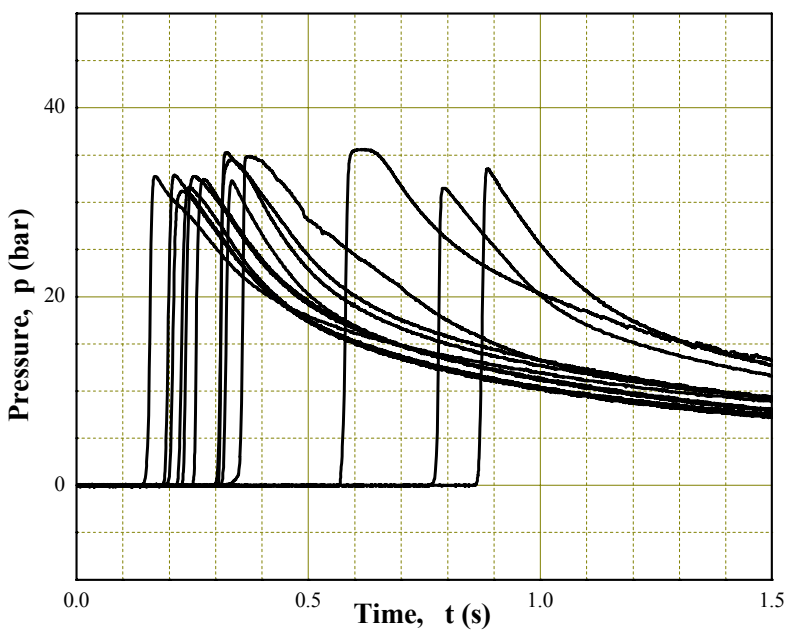

Figure 14. Pressure distributions
After the first series of tests with different granulations of the powder mixture, it was concluded that certain differences in pressure gradients exist from one to another test, but they are quite small and any regularity in the relations between the granulation of the ignition mixture and pressure gradient cannot be defined.

\section{Testing the ignition pellets}

The second part of the test was carried out with ignition mixtures in the form of tablets (pellets). Two different ignition mixtures were tested, as well as four combinations of five different tablet shapes and sizes (Fig.15).

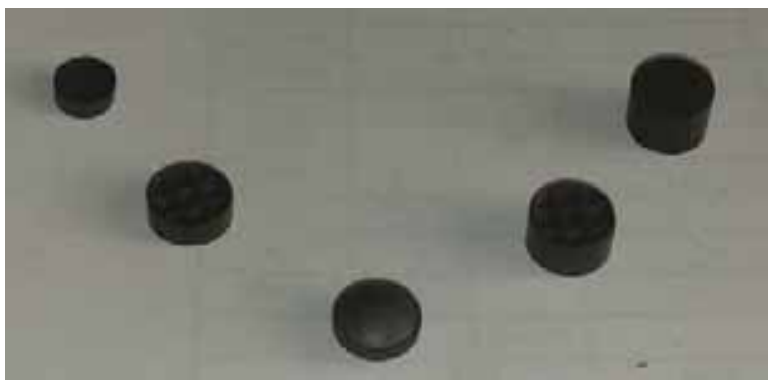

Figure 15. Three different types of tablets

The compositions of the two tested mixtures are shown in Table 1. In both cases potassium nitrate is used as oxidizer, and iditol as a binder. Magnesium was used as a fuel in the first mixture, and boron in the second mixture.

Table 1. Mixtures formulation

\begin{tabular}{|c|c|c|}
\hline \hline & Mixture - 1 & Mixture - 2 \\
\hline \hline $\mathrm{KNO}_{3}$ & 63.5 & 71.0 \\
\hline $\mathrm{Mg}$ & 33.5 & - \\
\hline $\mathrm{B}$ & - & 24.0 \\
\hline Iditol & 3.0 & 5.0 \\
\hline
\end{tabular}

All of the tested igniters contained exactly $3 \mathrm{~g}$ of the ignition mixtures, and their layout and weight of the tablets for different combinations is shown in Table 2.

Table 2. Different combinations of tablets

\begin{tabular}{||c|c|c|c|c|c|c||}
\hline \hline Comb. & \multicolumn{5}{|c||}{ Number of tablets } & Powder \\
\hline \hline & $0.24 \mathrm{~g}$ & $0.25 \mathrm{~g}$ & $0.5 \mathrm{~g}$ & $0.75 \mathrm{~g}$ & $1 \mathrm{~g}$ & $\mathrm{~g}$ \\
\hline 1. & 16 & - & - & - & - & 0.16 \\
\hline 2. & - & - & 5 & - & - & 0.50 \\
\hline 3. & - & 1 & - & 3 & - & 0.50 \\
\hline 4. & - & - & 1 & - & 2 & 0.50 \\
\hline
\end{tabular}

Summary chart with pressure distributions for all the performed tests is shown in Fig. 16.

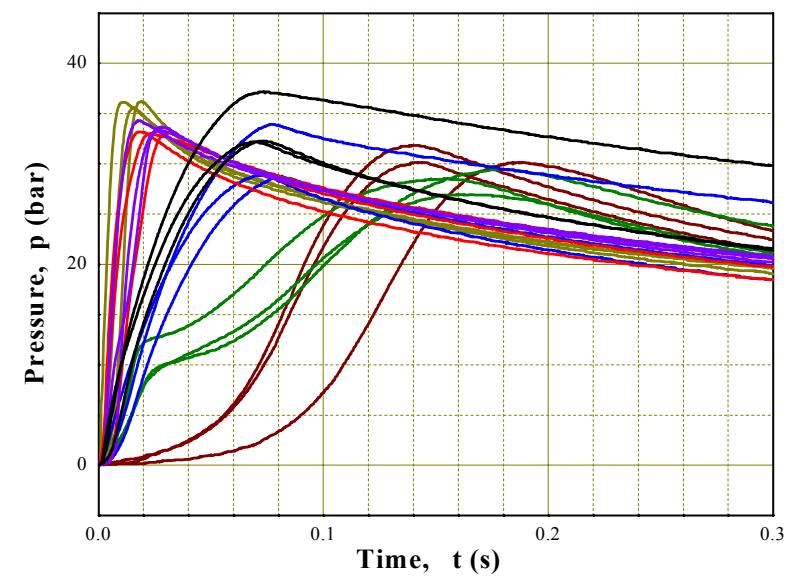

Figure 16. Pressure distributions - summary 
In Fig. 17 the pressure curves are compared for the two text mixtures in the form of small cylindrical tablets of $0.24 \mathrm{~g}$, defined as the combination $\mathrm{N}^{\mathrm{o}} .1$ in Table 2. There is a noticeable difference in the modes of pressure increase for these two mixtures.

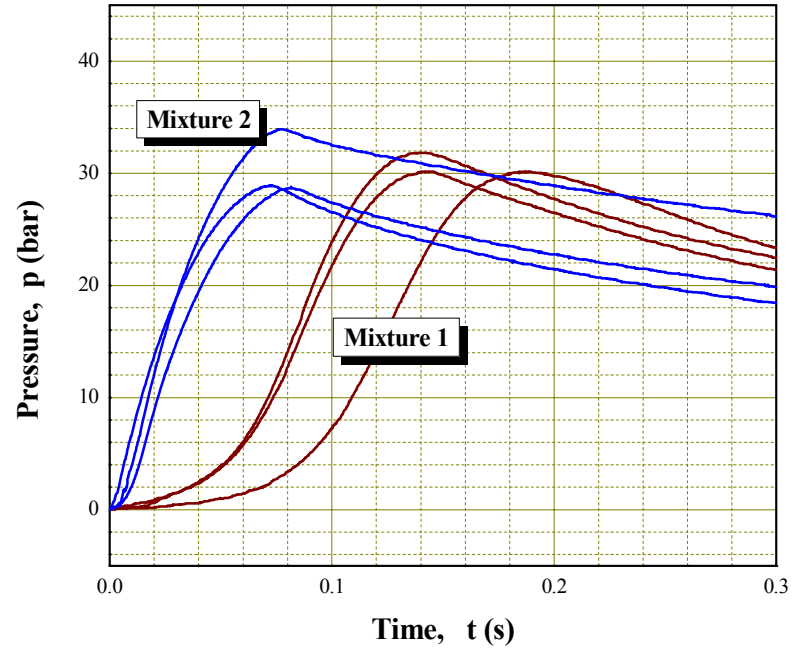

Figure 17. Pressure vs. time for the two mixtures and the first group of tablets $(0.24 \mathrm{~g})$

In Fig. 18 in the similar way a comparison is shown between the pressure curves for these two mixtures, this time with the tablets declared as combination $\mathrm{N}^{\mathrm{o}} .3$ in Table 2. There is also a visible difference in the regimes of pressure increase for these two mixtures.

In diagrams 17 and 18, two different compositions of the ignition mixtures were compared and it has been shown that there is a clear influence of the mixture formulation on the regime of pressure increase during ignition of an igniter itself.

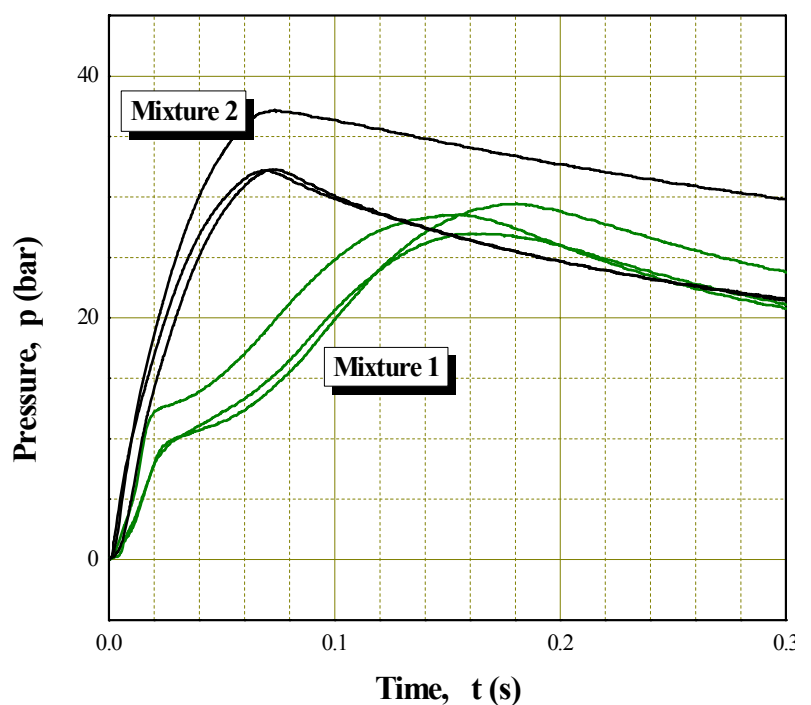

Figure 18. Pressure vs. time for the two mixtures and the third group of tablets $(3 \times 0.75 \mathrm{~g}+0.25+0.5$ powder $)$

In Fig.19 only one mixture has been considered (Mixture 2), with the boron as a fuel. The powder mixture and four different sets of tablets (Table 2) had been tested. It can be seen that it is possible to affect the pressure increase mode by selecting the shape and size of tablets.

\section{Discussion}

During the development of the solid propellant propulsion group for an antitank guided missile, the possibilities of achieving the desired control of ignition mode were analyzed, varying the composition and granulation of ignition mixtures.
In the first series of tests in the manometric bomb, the igniters with the mixture in powder form were tested.

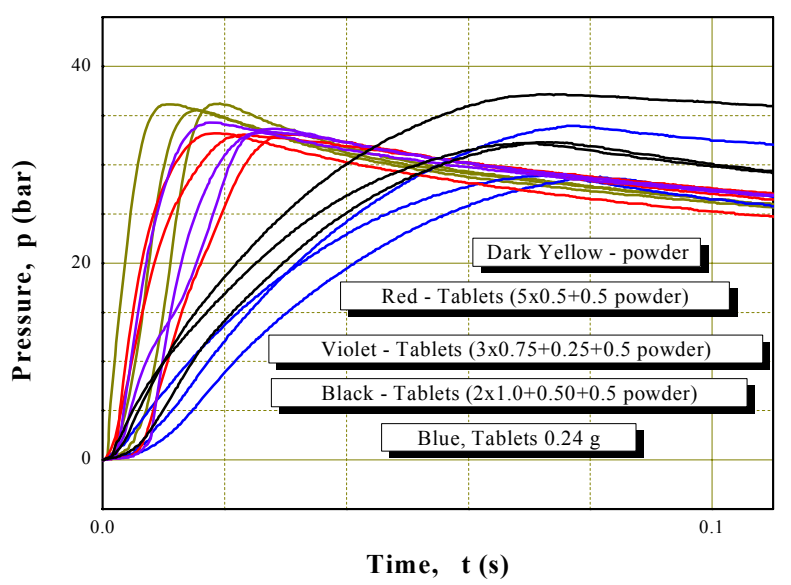

Figure 19. Pressure vs. time for all types of tablets of the mixture $2\left(\mathrm{BKNO}_{3}\right)$

Pressure vs. time curves were measured. Nine various mixture granulations were tested but no significant differences in the results of measurement were observed. Only the phase of increasing pressure was analyzed, until the moment of reaching maximum.

In the second round of tests, the igniters with the mixture in the form of tablets were tested. Two different mixtures were analyzed (Table 1), and four combinations (Table 2) made of 5 types of tablets (Fig.15).

There are clear differences between the two tested mixtures on their pressure distributions. A certain regularity can be seen. In the tests with the same mixture, with a variety of tablets, there are also visible differences that have a certain regularity.

Limited number of tests that were carried out, were not enough to define a mathematical dependence of the pressure rise due to the mixture composition and the size and shape of the tablets. However, these results are sufficient to encourage further experiments in the direction of achieving the desired regime of ignition.

\section{Conclusion}

The igniter tests made in the manometric bomb have shown that there are clear possibilities for controlling the process of pressure rise during the combustion of the igniter itself, and thus the process of ignition of the real rocket motor. Burning of the igniter itself is only one of the phases in the process of rocket motor ignition, but it significantly affects the whole regime of ignition.

The first results, in the first part of the experiment, showed that by changing granulation of the mixture in powder form it is not possible to affect the regime of pressure rise, because its influence is not sufficiently visible.

On the other hand, in the second part, it was concluded that it is possible to affect the pressure increase by the shape and composition of tablets made of ignition mixtures.

\section{References}

[1] SUTTON,G.P., BIBLARZ.O.: Rocket Propulsion Elements, Eighth edition. John Wiley \& Sons inc. ISBN: 978-0-470-08024-5, 2010.

[2] KUBOTA,N.: Survey of Rocket Propellants and their Combustion Characteristics, Chapter 4: C.E.Hermance, Solid Propellant Ignition Theories and Experiments, Vol.90 of Progress in Astronautics and Aeronautics, AIAA, New York, USA, 1984.

[3] ГЛИГОРИЈЕВИЋ,Н., ВУЈАЧИЋ,М., ПЕТРИЋ,А.: Повећање поузданости припаљивања ракетног мотора са чврстом композитном погонском материјом, 1990, ЈКЕМ 1990, Купари, YUGOSLAVIA, Зборник, Б2, стр. 620. 
[4] ВУЈОВИЋ,М.: Анализа процеса припаљивања ракетних мотора са чврстим горивом, Дипломски рад, 2018., Факултет инж. Наука, Крагујевац, SERBIA.

[5] NASA SP-8051: Solid Rocket Motor Igniters, March 1971.

[6] BARRERE,M., JAUMOTTE,A., BAUDOUIN FRAEIJS DE VEUBEKE, VANDENKERCKHOVE,J.: Rocket Propulsion, Elsevier Publishing Company, Amsterdam-London-New York, 1960.

[7] WIMPRESS,R.N.: Internal Ballistics of Solid-Fuel Rockets, McGrawHill Book Company, New York-Toronto-London, 1950.

[8] ЖИВКОВИЋ,С.: Испитивање прототипске партије припала мари мотора вођене ракете Бумбар, (Testing the prototype series of the igniters for the sustainer rocket motor of the guided missile Bumbar), Војнотехнички институт Београд, (Military Tecnical Institute, Belgrade), SERBIA, 2012.
[9] ЖИВКОВИЋ,С.: Маршевски ракетни мотор противоклопне вођене ракете Бумбар (Sustainer rocket motor of the guided missile Bumbar), техничко решење, Војнотехнички институт, Београд (Military Tecnical Institute, Belgrade), SERBIA, 2015.

[10] FIDANOVSKI, B., DIMIĆ, M., MILOJKOVIĆ, A., RODIĆ, V.: Determination of Chemical Stability of Propellants Using the Vacuum Stability Test Method, Scientific Technical Review, ISSN 1820-0206, 2016, Vol.66, No.1, pp.18-22.

[11] NIKOLIĆ, V., DIMIĆ, M., JOVANOVIĆ, S., GIRMAN, V.: Fe3O4 Nanoparticles as Additives for GAMMA-Ray Shielding: Structural and Surface Characterization, Scientific Technical Review, ISSN 18200206, 2017, Vol.67, No.2, pp.20-26.

\title{
Uticaj veličine čestica pripalne smeše na gradijent pritiska pripale raketnog motora
}

\begin{abstract}
U radu se razmatra uticaj granulacije pripalne smeše na režim pripaljivanja raketnog motora. Testovi sa pripalama su izvršeni u manometarskoj bombi i merena je vremenska promena pritiska. U svakom opitu su ispitivane pripale sa pripalnom smešom u obliku praha, ali sa različitim granulacijama iste smeše. Nakon toga, ispitivane su dve različite smeše u obliku tableta. Ispitivane su tri različite kombinacije veličina i oblika tableta. Ukupne mase pripalnih smeša su bile iste u svim opitima.

U prvoj seriji opita, u svakom testu su ispitivane pažljivo odabrane granulacije smeše u veoma uskim granicama. Od opita do opita menjane su samo granulacije smeše. Cilj ispitivanja je bio da se odredi da li postoji uticaj granulacije smeše na gradijent pritiska pripale, a time i na režim pripaljivanja raketnog motora. Ispostavilo se, neočekivano, da nema vidljivih razlika u režimima porasta pritiska u zavisnosti od granulacije smeše.

U narednoj seriji opita, ispitivana je smeša u obliku tableta. Od opita do opita menjane su veličine i oblik tableta. Ispitane su dve različite smeše. Pokazano je da i oblik tableta i njihov sastav imaju vidljiv uticaj na režim porasta pritiska pripale, čime može da se utiče na režim pripaljivanja raketnog motora.
\end{abstract}

Ključne reči: raketni motor, pripaljivanje, pripala, pritisak, gradijent pritiska, pripalna smeša, granulacija, tablete.

\section{Influence de la taille des particules du mélange d'allumage sur le gradient de pression d'allumeur du moteur à fusée}

\begin{abstract}
Dans ce papier on considère l'influence de la granulation du mélange d'allumage sur le régime d'allumage du moteur à fusée. Les tests avec l'allumage ont été effectués dans la bombe manomètre et on a mesuré le changement temporel de la pression. Pendant chaque test on a examiné les allumages avec le mélange d'allumage en forme de poudre mais avec les différentes granulations du même mélange . Ensuite on a examiné deux différents mélanges en forme de comprimés. Trois différentes combinaisons de formes et de taille de comprimés ont été testés. Les masses totales des mélanges d'allumage étaient égales dans tous les tests. Dans la première série de tests les mélanges des granulations choisies très attentivement pour chaque test ont été examinés dans les très étroites limites. D'un test à l'autre on a changé seulement les granulations de mélanges. Le but de l'examen était de déterminer s'il existe l'influence du mélange de granulation sur le gradient de pression d'allumage et ainsi sur le régime d'allumage du moteur à fusée. II s'est révélé inopinément qu'il n'y avait pas de visibles différences dans les régimes de l'augmentation de pression dues à la granulation de mélange. Lors de la suivante série des tests on a examiné le mélange en forme de comprimés. De test à l'autre on a changé les tailles et les formes des comprimés. On a examiné deux mélanges différents. On a démontré que la forme et le contenu des comprimés ont l'influence visible sur le régime de la croissance de pression d'allumage ce qui peur affecter considérablement le régime d'allumage chez le moteur à fusée.
\end{abstract}

Mots clés: moteur à fusée, allumage allumeur, pression, gradient de pression, mélange d'allumage, granulation, comprimés.

\section{Влияние размера частиц смеси воспламенения на градиент давления горения ракетного двигателя}

В статье рассматривается влияние грануляции смеси воспламенения на режим включения ракетного двигателя. Испытания с воспламенителями проводились в манометрической бомбе, и измерялось временное изменение давления. В каждом эксперименте воспламенитей исследовали порошкообразной смесью воспламенения, но с различными грануляциями той же смеси. После этого были исследованы две разные смеси-таблетки. Были 
исследованы три различные комбинации размера и формы таблеток. Общая масса смесь воспламенения была одинаковой во всех экспериментах.

В первой серии экспериментов, в каждом тесте были исследованы тщательно отобраны гранулы смеси в очень узких границах. Из эксперимента в эксперимент были изменены только гранулирования смеси. Цель теста состояла в том, чтобы определить, был ли эффект влияния гранулирования смеси на градиенте давления воспламенителя , и, следовательно, на режим включения ракетного двигателя. Неожиданно оказалось, что нет заметных различий в режимах повышения давления в зависимости от грануляции смеси.

В следующей серии экспериментов была протестирована таблетка. Из эксперимента в эксперимент были изменены размеры и формы таблеток. Были исследованы две различные смеси. Было показано, что как формы таблеток, так и их состав оказывают заметное влияние на режим повышения давления воспламенителя, который может влиять на режим включения ракетного двигателя.

Ключевые слова: ракетный двигатель, зажигание, воспламенитель, давление, градиент давления, смесь воспламенения, грануляция, таблетки. 